\section{Biogen antibody may not be immune to side effects}

Phase II trials of Antova, an anti-CD40 monoclonal antibody being tested by Biogen (Cambridge, MA) against a variety of conditions, including multiple sclerosis, reverse transplant, and thromobcytopenic purpura were suspended or delayed in October. Preliminary results suggested that the antibody might cause adverse side effects; one trial patient died. Biogen refused to comment on the total number of patients involved, or whether the death was caused by a thromboembolic event (the formation of large, potentially fatal blood clots), but Biogen representatives have said that they are investigating a thromboembolic event in other patients. Kathryn Bloom, a spokesperson for Biogen, stresses that "everyone has to understand that many of the patients coming into the trials were very ill ... and because of their underlying disease at much higher risk for [a thromboembolic event]." Despite such assurances, Biogen shares dropped $\$ 83 / 16$ to $\$ 643 / 8$, or $11 \%$, on October 22 , the morning after the announcement. Analysts have said that the status of Antova is a key indicator of Biogen's long-term potential, because the company has only one product approved. The market for the MS indication alone is approximately $\$ 500$ million to $\$ 1$ billion, according to analysts' projections.

\section{US bill seeks GMO labeling}

Rep. Dennis Kucinich (D-OH) introduced legislation in the US House of Representatives in mid-November calling for mandatory labeling of all foods derived from genetically modified organisms. This proposed, comprehensive "consumers' right to know" law specifies wording for a standardized label and also outlines a system for determining whether GM materials were introduced into a food during any stage of manufacture and production. Michael Phillips of the Biotechnology Industry Organization (Washington, DC) calls the bill "entirely unnecessary" and says that such labeling would "confuse consumers by suggesting that the process of biotechnology might in and of itself have an impact on the safety of food." Meanwhile, President Clinton, speaking before members of an agricultural group in Arkansas, endorsed the current federal approach for evaluating the safety of GM crops.

Business and Regulatory Briefs written by Emma Dorey, Alan Dove, Jeffrey Fox, John Hodgson, Eric Niiler, and Asako Saegusa.

\section{Fujitsu joins Japan's Bionet}

Fujitsu, Japan's largest computer maker, is to join hands with the Biomolecular Engineering Research Institute (BERI; Osaka), Japan Bioindustry Association (Tokyo), and universities to launch a webbased biotechnology network, Japanese Bionet, to promote interaction between industry and researchers. By partnering with international companies, Japanese Bionet will provide consultation services to biotechnology-related ventures and researchers planning to set up new businesses. Partners already include Oxford Molecular (Oxford, UK), which supplies bioinformatics products and research services for drug discovery; the US chemical software company Cambridge Soft Corporation (Cambridge, MA); and Beilstein Informationssysteme (Frankfurt), the German chemical database company. Bionet will supply companies and researchers with information and advice on gene and protein analysis, creation of biological databases, and information technology required for discovery of new drugs and chemicals. Fujitsu, which plans to set up part of its network service by the end of the year, says its ultimate aim is to provide information and services related to "personalized medicine."

\section{Leptin efficacy looks slim}

Results of the first clinical trial of the hormone leptin as a treatment for obesity suggest that the "miraculous" results seen in obese mice might not be duplicated in humans. The phase I study, sponsored by Amgen and reported in the October 27 issue of the Journal of the American Medical Association, followed 127 volunteers who injected themselves with various doses of the hormone or a placebo. At the highest dose, only two out of eight patients lost substantial amounts of weight, while one gained nearly $9 \mathrm{~kg}$. Ten patients dropped out of the study because of the unpleasant regimen of several injections daily. According to David Kay, a spokesman for Amgen, the company is now working on a leptin formulation that should remain active in the bloodstream longer, reducing the number of injections required.

Obesity researchers have noted that in earlier studies leptin demonstrated efficacy in treating one extremely rare form of obesity, in which a patient fails to make leptin. But with an estimated worldwide market of six patients, this indication is unlikely to cover the drug's development costs.

\section{GMO roundup}

- The poetry section of the Artactivist web site (www.artactivist.com/poetry.html) recommends numerous wholesome and educational ditties for modern parents to teach their children. Adapted from the traditional English nursery rhymes "Baa Baa Black sheep / Have you any wool?" is a version that starts promisingly, "Strange Sheep, Strange Sheep / Have you any genes?" Throwing scansion and biology aside, however, it then continues: "Yes, Sir. Yes, Sir / I have three / One from the ewe / One from the ram / One from the lab boy who lives down the lane." Equally cutting and accurate is a stirring adaptation of the humorous song, "There's a hole in my bucket." In 10 verses, it tells a tale of herbicide-resistant plants, starting: "There's Roundup in my Canola / Monsanto, Monsanto / There's Roundup in my Canola / Monsanto, Roundup."

- Part of a communiqué from "Reclaim the Seeds" explains the angst of the eco terrorists as they destroy plant research plots (mostly nontransgenic) in California. "The act of taking the life of a plant is serious, and one we don't take lightly. Before anyone embarks on such a course, we believe it important to think through the moral dimensions of crop-pulling, and come into it with a strong heart. It would also be wise to make some sort of a prayer, offering, or explanation to the crops whose individual lives you will be taking in order to defend the sanctity of all life."

- Self-styled UK eco-warrior Tommy Archer was found not guilty of criminal damage after he destroyed an experimental plot of GM herbicide-resistant oilseed rape and assaulted a local farmer near the village of Ambridge in Borsetshire. Although Archer admitted destroying the crop, the majority jury verdict was that he had "just cause" to do so because he genuinely believed that the crop was a threat to his father's nearby organic farm. The share price of Bealtech, the company that developed the rape, was unaffected by the decision. Observers from the legal profession believe that the case is unlikely to set a precedent for similar British cases, largely because it was a storyline in the popular $\mathrm{BBC}$ radio soap opera, The Archers.

- An anonymous correspondent commented after reading Arpad Pusztai's Lancet paper on the effects of feeding rats potatoes containing lectin: "I haven't eaten a single snow-drop, since reading Professor Pusztai's frightening paper." 